\title{
Examining the Factors of Endogenous Development in Hungarian Rural Areas by Means of PLS Path Analysis
}

Péter Kovács

University of Szeged

Faculty of Economics and

Business Administration, Fac-

ulty of Law

Department of Statistics and

Demography

E-mail:

kovacs.peter@eco.u-szeged.hu

Gábor Bodnár

Szent István University

Faculty of Agricultural and

Economic Science

Institute of Economic Science

and Methodology

E-mail:

bodnar.gabor@gk.szie.hu

Keywords:

PLS path analysis, endogenous development,

forms of capital,

dependencies,

rural areas
The study analyses the development of Hungarian rural sub-regions. After the delimiting of the countryside, we focus on the academic literature of endogenous regional development. There are many approaches to the theory and, thus, there are differences and similarities between the key factors of the theory. We synthesize these forms of capital to create a conceptual framework that can serve as a basis for quantitative analyses. We propose our own measuring system and a model to reveal the relations among endogenous capital factors in the framework of a descriptive analysis, relying on the theory of endogenous development. Furthermore, we propose a model that explains development, and includes latent variables symbolising the forms of capital. We then examine the model using a partial least squares path analysis. The results show that the various forms of capital thought to be relevant in the literature are not all included in the regression model. This shows and helps us to understand the connections between forms of capital, although the model is only valid in a rural context. Furthermore, we find that the relations between the forms of capital vary considerably over time.

\section{Introduction}

Despite the fact that rural areas in East-Central Europe struggle with many difficulties, in a wider context of the countryside, we can discuss numerous changes. In the past few decades, the theory of endogenous development has come to the fore in spatial development and regional policy, and has gained relevance in a rural context. However, in the case of the countryside, the emphases are slightly different.

Nevertheless, empirical analyses of the popular theory of endogenous development, including probably the most popular concept of territorial capital, place cities 
or territorial units on a particular hierarchical level. These analyses either neglect the countryside, or place minimal focus on them.

Today, endogenous development is a highly valued branch of development theory. Concerning the notion itself, Lengyel states that "...endogenous, in economics, means the factors which are not inherited ("not born of God") but created consciously by economic activities. In regional science the bottom-up organised public actions and initiatives, which are based on consciously created local facilities are regarded as endogenous" (Lengyel 2012, p. 145).

The utilization of local facilities is sometimes ambiguous, which can cause significant disadvantages. The appreciation of undercover facilities mentioned above highlights the real problem with the devalued Hungarian countryside.

Capello et al. (2009) believe that at least two conditions are essential. The first is local production and the appropriate utilization of knowledge. The second is territorial capital, which respects the specialities of a given region.

Our aim is to analyse the interaction among forms of capital in terms of endogenous development. We focus on the rural sub-regions of Hungary, which we investigate using partial least squares (PLS) path analysis. However, we first clarify the term 'rural' and its relevant data.

\section{Countryside and delimitation}

The countryside is a unique territory that differs from urban settlements, and has special characteristics that are determined by the settlements, economy, and society surrounding it. Rural areas have an irreplaceable economic, social, cultural and ecological importance (Perlín-Simciková 2008). That the functions of rural territories do not only serve trade in the suburbs, agriculture, and tourism was first mentioned in a regional development document (EC 1999) more than a decade and a half ago. This statement is even more relevant today, because most of the cultural and biological diversity of the European Union can be attributed to such territories.

In order to define rural territories, we base our analysis on the Hungarian system of sub-regions, and use the recommendations of Csatári (2001). As such, we can categorize Hungarian minor territorial units using the urban/rural index; that is, we determine the ratio of residents in territories with a density below and above 120 people $/ \mathrm{km}^{2}$.

The urban/rural index considers 106 territorial units to be rural, although the features of these areas do vary. However, this is a widely accepted method, note that each rural area includes one or more cities.

Regional Statistics, Vol. 7. No.1. 2017: 090-114; DOI: 10.15196/RS07106 


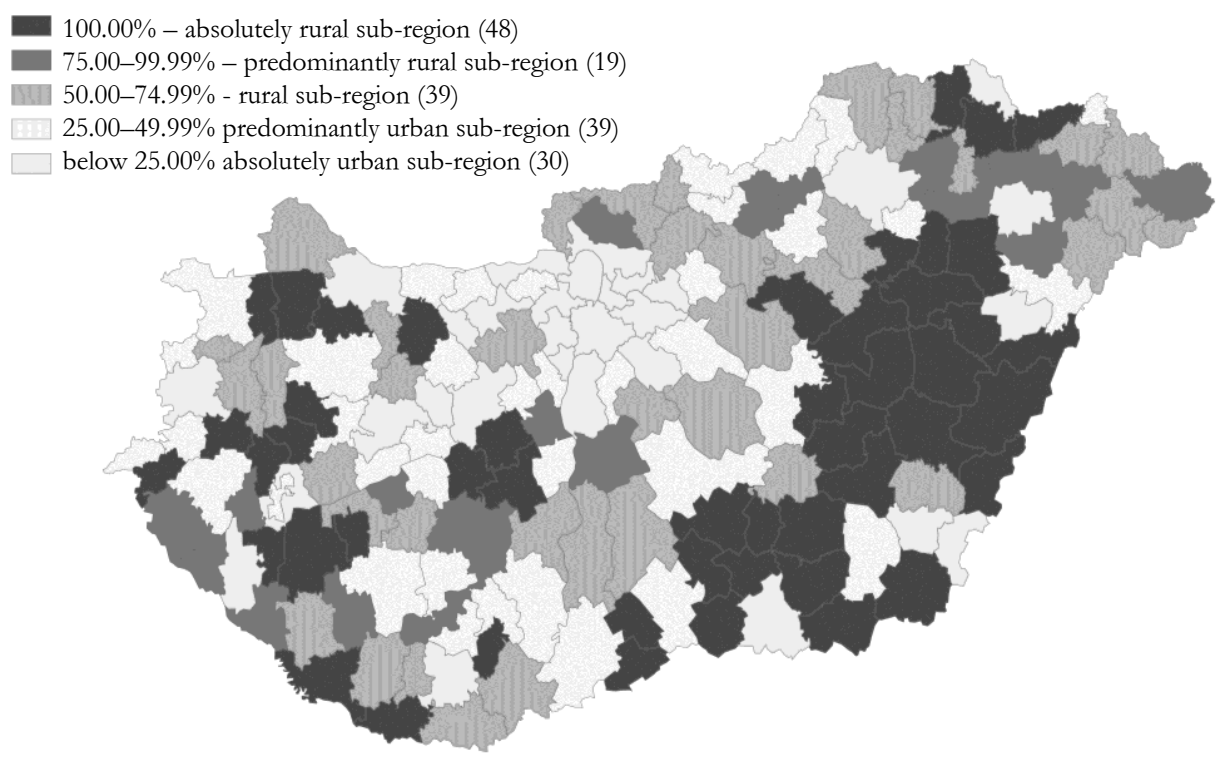

Source: Own creation.

\section{Theory of endogenous development}

Next, we determine the relevant forms of capital in the context of endogenous development. However, we first briefly describe the theory of endogenous development, which is based on the notion of development.

"The concept of development, according to its most general interpretation, means the process which leads from a lower standard to a higher one" (Szentes 2011, p. 13). Szentes (2011) highlights that the theory of development has had diverse interpretations over time, and particularly in the recent past, depending on the branch of social science in which it is applied. The definitional problem is also mentioned by Todaro and Smith (2009), who claim that without a certain level of agreement, we cannot carry out quantitative analyses or determine the development within a country. The authors add that the strict economic definition of development refers to long-term income per capita growth that enables a faster output than the population growth of a nation.

According to Benko (1997), endogenous development appeared in the late 1980s, although the author refers only to industrial and urban regions in his study. Stimson et al. (2011) claim that the past few decades have seen a shift from exogenous to endogenous facilities. Supporting this finding, Lengyel (2012/a) states that endogenous factors have recently come to the fore in regional development.

Regional Statistics, Vol. 7. No.1. 2017: 090-114; DOI: 10.15196/RS07106 
Then, Capello's $(2007,2011)$ view is that endogenous development depends on a regions' constitution, which is a socio-economic and cultural system defining the success of local economy via the elements of entrepreneurial skills, local factors of production (labour and capital), and contact management of local actors, which increasingly contribute to the creation of knowledge.

These conditions are important, because several statistically significant territorial differences should not be attributed to the inefficient use of the classic factors of production, such as capital and labour, but rather are the result of more deeply rooted regional problems, such as local geographical facilities, openness, creativity, and entrepreneurial milieu (Capello et al. 2009). Capello and Nijkamp (2011) mention social opportunities, a healthy environment, and high-quality education as factors determining the regional aspect of economic development.

In order to determined the importance of each form of capital, we consider a wide selection, from which we choose those that are the most appropriate (see Table 1).

Table 1

Forms of capital in models of endogenous development

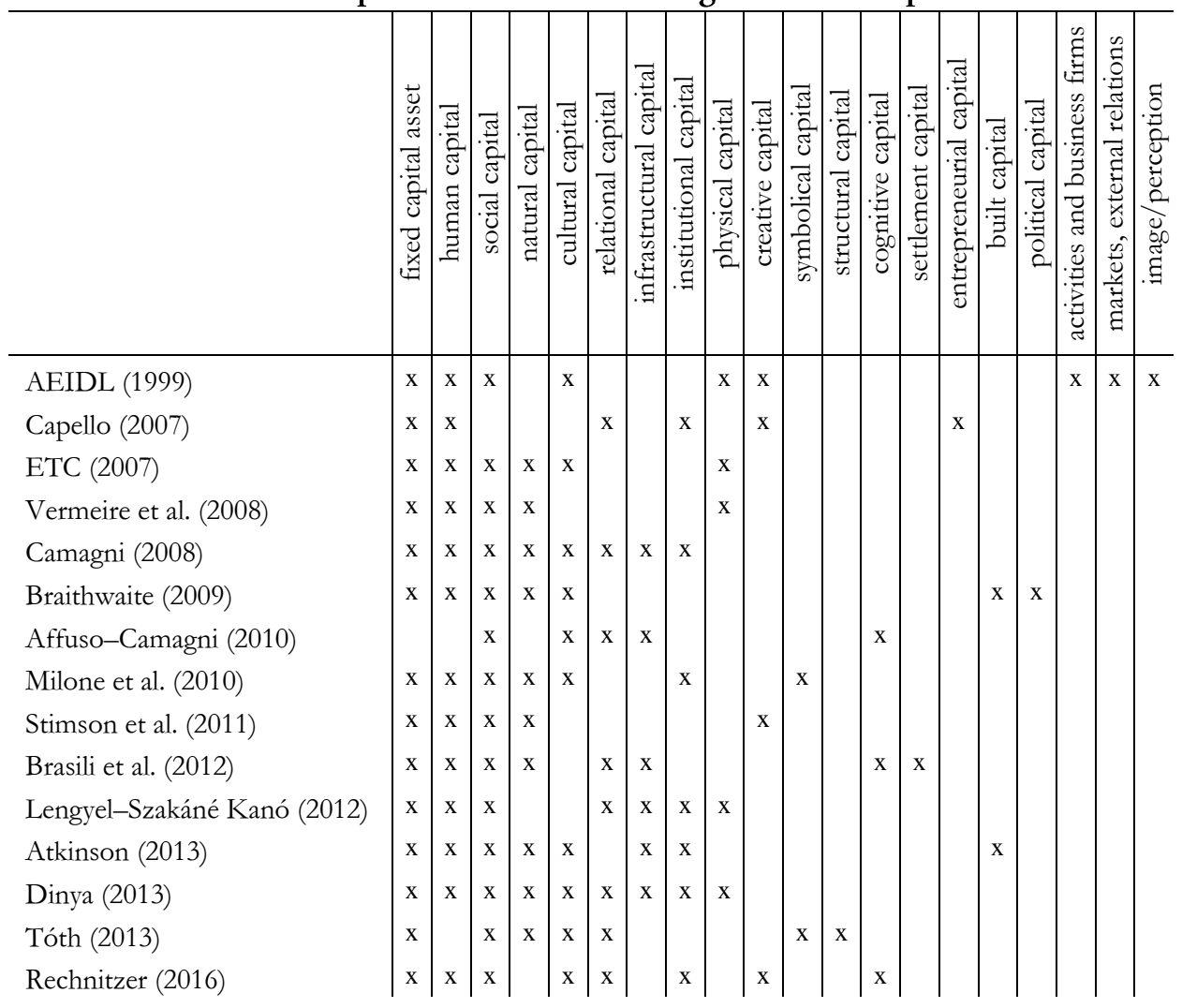

Source: Own creation; based on Tóth (2013, p. 44.)

Regional Statistics, Vol. 7. No.1. 2017: 090-1 14; DOI: 10.15196/RS07106 
The most frequent and important forms of capital, which we attempt to include in our model, are the following: fixed capital, human capital, social capital, natural capital, cultural capital, relational capital, and infrastructural capital ${ }^{1}$.

It is a common attribute of the forms of capital that they are all highly relevant in the rural context, where they appear in a special form. The role of the classic form of capital is unambiguous, and the importance of natural capital to rural areas is self-evident.

The table shows that the same elements are mentioned in several endogenous models as key factors. For example, fixed capital stock appears in many theories, and human capital is important as well. Social capital, natural capital, built capital, and cultural and relational capital are also important. Thus, we treat these as the fundamentals of our quantitative analysis.

Note that we partly agree with Jóna (2013), who adapts Camagni's conception into seven elements. While we interpret the forms of capital in Table 1, we also include natural capital, because the cell in the bottom, left corner of the table can be understood as a natural resource in Camagni's (2008) system.

See Table 2 for a brief summary of these elements.

Table 2

\section{Forms of capital}

\begin{tabular}{|c|c|c|c|}
\hline Form of Capital & Definition & Examples of indicators & Source \\
\hline $\begin{array}{l}\text { Private fixed capi- } \\
\text { tal (wealth) }\end{array}$ & \multirow{2}{*}{$\begin{array}{l}\text { Private fixed capital is a } \\
\text { derived element, and it has } \\
\text { been created as a factor of } \\
\text { production. It is deter- } \\
\text { mined by a high level of } \\
\text { materiality and rivalry in } \\
\text { Camagni's (2008) model } \\
\text { (as well). }\end{array}$} & \multirow{2}{*}{$\begin{array}{l}\text { Financial characteristics of } \\
\text { inhabitants and enterprises, } \\
\text { local structure of economy, } \\
\text { standard of services, indicators } \\
\text { of multinational companies, } \\
\text { labour productivity, industrial } \\
\text { indicators }\end{array}$} & \multirow{2}{*}{$\begin{array}{l}\text { Brasili et al. (2012) } \\
\text { Camagni et al. } \\
\text { (2011) } \\
\text { Jóna (2013) } \\
\text { Tóth (2013) }\end{array}$} \\
\hline $\begin{array}{l}\text { Entrepreneurial } \\
\text { milieu (fixed capi- } \\
\text { tal no. 2) }\end{array}$ & & & \\
\hline $\begin{array}{l}\text { Infrastructural } \\
\text { capital }\end{array}$ & $\begin{array}{l}\text { 'Infrastructural capital is } \\
\text { usually referred to as a } \\
\text { support system created by } \\
\text { people to carry out eco- } \\
\text { nomic activities in the best } \\
\text { possible conditions, in } \\
\text { terms of both time and } \\
\text { savings. Hence, infrastruc- } \\
\text { tural capital is composed } \\
\text { of the set of communica- } \\
\text { tion means (roads, airports, } \\
\text { railways) that expedite and } \\
\text { facilitate the exchange of } \\
\text { people, goods and services' } \\
\text { Brasili et al. (2012, p. 13). }\end{array}$ & $\begin{array}{l}\text { Indicators belonging to public } \\
\text { utilities, indicators of natural } \\
\text { environment, settlement struc- } \\
\text { ture }\end{array}$ & $\begin{array}{l}\text { Affuso-Camagni } \\
\text { (2010) } \\
\text { Brasili et al. (2012) } \\
\text { Jóna (2013) } \\
\text { Tóth (2013) }\end{array}$ \\
\hline
\end{tabular}

(Table continues on the next page.)

\footnotetext{
${ }^{1}$ Indicators of each capitals can be seen in Annex I.
}

Regional Statistics, Vol. 7. No.1. 2017: 090-114; DOI: 10.15196/RS07106 
(Continued.)

\begin{tabular}{|c|c|c|c|}
\hline Form of Capital & Definition & Examples of indicators & Source \\
\hline Natural capital & $\begin{array}{l}\text { As Buday-Sántha (2006, p. } \\
352 \text { ) describes, natural cap- } \\
\text { ital is ' } . . \text { those kind of } \\
\text { stock of natural resources } \\
\text { and environmental assets } \\
\text { which can supply precious } \\
\text { goods for mankind nowa- } \\
\text { days and in the future'. }\end{array}$ & $\begin{array}{l}\text { Indicators belonging to tour- } \\
\text { ism, pollution, environmental } \\
\text { protection expenditures, green } \\
\text { areas, sustainable agriculture, } \\
\text { running water service, built-up } \\
\text { density }\end{array}$ & $\begin{array}{l}\text { Affuso-Camagni } \\
\text { (2010) } \\
\text { Brasili et al. (2012) } \\
\text { Tóth (2013) }\end{array}$ \\
\hline Social capital & $\begin{array}{l}\text { Social capital refers to } \\
\text { '...features of social life- } \\
\text { networks, norms, and trust } \\
\text { that enable participants to } \\
\text { act together more effec- } \\
\text { tively to pursue shared } \\
\text { objectives' (Putnam 1996, } \\
\text { p. 66). }\end{array}$ & $\begin{array}{l}\text { Indicators of unemployment, } \\
\text { crime, tourism; social indica- } \\
\text { tors; participation in public } \\
\text { life; volunteering; donations }\end{array}$ & $\begin{array}{l}\text { Affuso-Camagni } \\
(2010) \\
\text { Brasili et al. (2012) } \\
\text { Jóna (2013) } \\
\text { Tóth (2013) }\end{array}$ \\
\hline Human capital & $\begin{array}{l}\text { 'Human capital refers to } \\
\text { the set of skills, competen- } \\
\text { cies, abilities owned by the } \\
\text { individuals' (Camagni et al. } \\
2011, \text { p. 6). }\end{array}$ & $\begin{array}{l}\text { Data belonging to education, } \\
\text { tertiary education, research } \\
\text { and development, culture }\end{array}$ & $\begin{array}{l}\text { Brasili et al. (2012) } \\
\text { Camagni et al. } \\
\text { (2011) } \\
\text { Jóna (2013) } \\
\text { Tóth (2013) }\end{array}$ \\
\hline Cultural capital & $\begin{array}{l}\text { "Bourdieu (...) developed } \\
\text { the concept of "cultural } \\
\text { capital" to explain the abil- } \\
\text { ity of elite managers and } \\
\text { professionals to transmit } \\
\text { their privileged status to } \\
\text { their children, a process he } \\
\text { referred to as "social and } \\
\text { cultural reproduction" } \\
\text { (DiMaggio 2004, p. 167). }\end{array}$ & Data belonging to culture & Jóna (2013) \\
\hline Relational capital & $\begin{array}{l}\text { Relational capital is de- } \\
\text { scribed by Sik ( } 2006, \mathrm{p} \text {. } \\
77 .) \text {, based on two condi- } \\
\text { tions, who states '... it is } \\
\text { capable to co-create goods } \\
\text { and services meanwhile it } \\
\text { does not transform itself; } \\
\text { moreover to produce rela- } \\
\text { tional capital it is necessary } \\
\text { to make sacrifices in the } \\
\text { hope of future success } \\
\text { (which can be failure, so it } \\
\text { is a hazardous investment)'. }\end{array}$ & $\begin{array}{l}\text { Turnout in elections, exporting } \\
\text { ability, level of openness, } \\
\text { amount of active spin-off } \\
\text { companies, minorities, figures } \\
\text { of telecommunication, non- } \\
\text { profit organizations, data be- } \\
\text { longing to clubs for senior } \\
\text { citizens }\end{array}$ & $\begin{array}{l}\text { Affuso-Camagni } \\
(2010)^{2} \\
\text { Brasili et al. (2012) } \\
\text { Jóna (2013) } \\
\text { Tóth (2013) }\end{array}$ \\
\hline
\end{tabular}

Source: Own creation

${ }^{2}$ Affuso and Camagni (2010) handle social and relational capital as a single form.

Regional Statistics, Vol. 7. No.1. 2017: 090-114; DOI: 10.15196/RS07106 
Note that we regard to Table 2, the quantitative approach of fixed capital assets was not clear, despite our studying the literature. Thus, we decided to create two separated forms: private fixed capital, which expresses individual wealth, an entrepreneurial milieu, which reflects the wealth of companies.

\section{PLS path analysis - original model}

In this section, we attempt to determine the importance of each selected form of capital using a PLS path analysis. Moreover, we investigate the interactions among the forms of capital and their effect on development. It is important that we do so in order to allow for temporal and spatial changes. With the help of a PLS path analysis, we run a factor and a regression analysis simultaneously, enabling us to analyse the direct and indirect effects among the latent variables (Henseler 2010, Kazár 2014). The advantage of the PLS method is that it can be used in the case of small samples and nonnormal distributed variables (Hair et al. 2012). To analyse the relations between latent factors, we used a PLS path analysis with SmartPLS 3. We use a regression model based on the created latent variables. The results show the weight and importance of each factor in the Hungarian countryside. Then, we investigate the effects of the abovementioned elements on a simplified concept of wellbeing, interpreted as private fixed capital ${ }^{3}$.

Note that our model has an aim of confirmation. As Münnich and Hidegkuti (2012) describe we supervise the relevancy of used data because the links between them are hypothetical.

The PLS path model has an inner and outer part. The inner model can be understood as a collective of the latent variables, and the interactions among them. The outer model contains the elements (indicators) of each factor. The variables towards the top of the inner model (Figure 2) are non-material elements, and those towards the bottom denote material elements.

For all three years, we construct an original model of dependencies (Figure 2). We assume that cultural, human, and relational capital shape social capital directly. Furthermore, we assume that social capital has the same effects on private fixed capital and the entrepreneurial milieu, and that relational capital is shaped by cultural capital. Moreover, we hypothesize that infrastructural capital has a direct and significant effect on private fixed capital and the entrepreneurial milieu. Natural capital also forms part of the entrepreneurial milieu.

\footnotetext{
${ }^{3}$ The concept of well-being is understood as a synonym of private fixed capital, which is an exaggerated simplification, but helps with the interpretation of our aims.
}

Regional Statistics, Vol. 7. No.1. 2017: 090-114; DOI: 10.15196/RS07106 
Dependencies of elements describing private fixed capital - original model

Figure 2

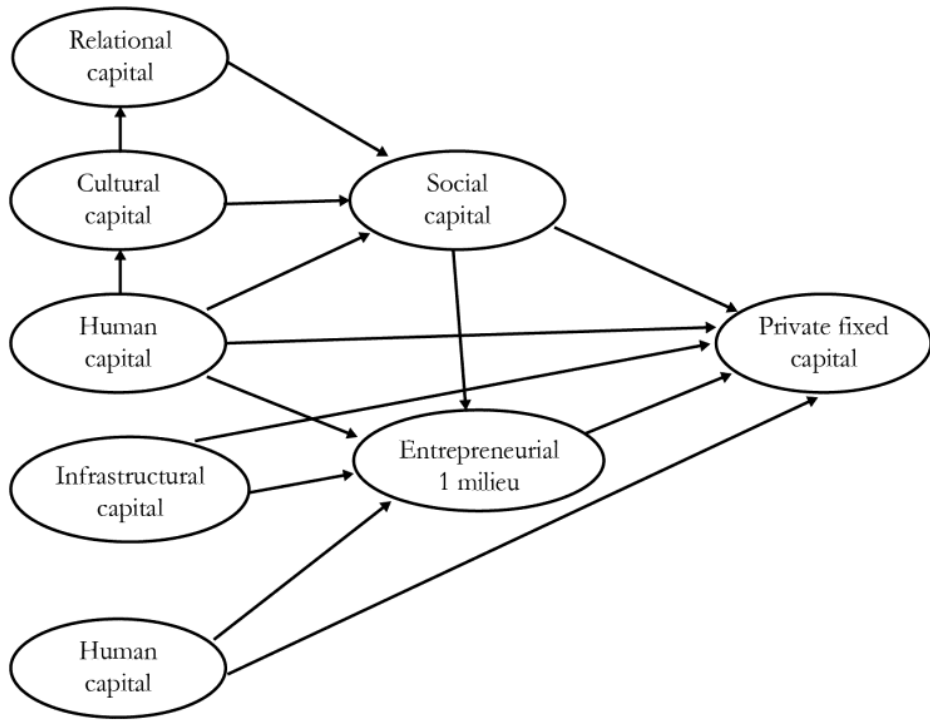

Source: Own creation.

Table 3

Attributes of forms of capital

\begin{tabular}{l|c|c|c|c|c|c|c|c|c}
\hline \multirow{2}{*}{\multicolumn{1}{c}{ Factor }} & \multicolumn{3}{c|}{ Cronbachs Alpha } & \multicolumn{3}{c|}{ Composite Reliability } & \multicolumn{3}{c}{$\begin{array}{c}\text { Average Variance } \\
\text { Extracted (AVE) }\end{array}$} \\
\cline { 2 - 11 } & 2009 & 2011 & 2013 & 2009 & 2011 & 2013 & 2009 & 2011 & 2013 \\
\hline Human capital & 0.793 & 0.783 & 0.764 & 0.838 & 0.834 & 0.820 & 0.515 & 0.509 & $0.485^{*}$ \\
Infrastructural capital & 0.762 & 0.733 & 0.767 & 0.841 & 0.822 & 0.843 & 0.518 & $0.484 *$ & 0.518 \\
Relational capital & 0.803 & 0.682 & 0.760 & 0.866 & 0.754 & 0.791 & 0.645 & 0.531 & 0.556 \\
Cultural capital & 0.785 & 0.764 & 0.762 & 0.857 & 0.841 & 0.841 & 0.544 & 0.515 & 0.505 \\
Private fixed capital & 0.811 & 0.820 & 0.843 & 0.874 & 0.873 & 0.894 & 0.557 & 0.540 & 0.591 \\
Natural capital & 0.743 & 0.743 & 0.722 & 0.798 & 0.838 & 0.829 & 0.573 & 0.634 & 0.619 \\
Social capital & 0.852 & 0.836 & 0.853 & 0.894 & 0.885 & 0.897 & 0.630 & 0.614 & 0.638 \\
Entrepreneurial milieu & 0.781 & 0.820 & 0.841 & 0.843 & 0.875 & 0.893 & 0.510 & 0.564 & 0.593
\end{tabular}

*: Lower than required result.

Source: Own creation.

In order to describe the latent constructions, we first examine the internal consistency, which can be measured by Cronbach's alpha. A value of 0.6 or higher can be accepted. When the PLS algorithm is applied, Cronbach's alpha often underestimates the level of internal consistency, because it assumes the equality of loadings. In order to solve this problem, the composite reliability indicator is applied, which considers the differences

Regional Statistics, Vol. 7. No.1. 2017: 090-1 14; DOI: 10.15196/RS07106 
among the loadings. In this case a value of 0.7 or higher can be accepted (KovácsBodnár 2016). In our examination, these conditions were satisfied (see Table 3).

Table 4

Values of the HTMT correlation ratio

\begin{tabular}{|c|c|c|c|}
\hline \multirow{2}{*}{ Pairs of latent variables } & \multicolumn{3}{|c|}{ HTMT P Values } \\
\hline & 2009 & 2011 & 2013 \\
\hline Infrastructural capital - Human capital & 0.733 & 0.697 & 0.703 \\
\hline Relational capital - Human capital & -0.062 & -0.052 & -0.066 \\
\hline Relational capital - Infrastructural capital & 0.514 & 0.558 & 0.573 \\
\hline Cultural capital - Human capital & 0.062 & 0.063 & 0.147 \\
\hline Cultural capital - Infrastructural capital & 0.586 & 0.638 & 0.600 \\
\hline Cultural capital - Relational capital & 0.587 & 0.392 & 0.321 \\
\hline Private fixed capital - Human capital & 0.579 & 0.539 & 0.587 \\
\hline Private fixed capital - Infrastructural capital & $0.994 *$ & 0.881 & 0.813 \\
\hline Private fixed capital - Relational capital & 0.204 & 0.214 & 0.198 \\
\hline Private fixed capital - Cultural capital & 0.387 & 0.348 & 0.360 \\
\hline Natural capital - Human capital & -0.073 & -0.071 & -0.112 \\
\hline Natural capital - Infrastructural capital & 0.164 & 0.179 & 0.042 \\
\hline Natural capital - Relational capital & 0.145 & 0.161 & 0.139 \\
\hline Natural capital - Cultural capital & 0.453 & 0.404 & 0.314 \\
\hline Natural capital - Private fixed capital & 0.132 & 0.111 & 0.082 \\
\hline Social capital - Human capital & -0.513 & -0.570 & -0.597 \\
\hline Social capital - Infrastructural capital & -0.761 & -0.889 & -0.809 \\
\hline Social capital - Relational capital & -0.094 & -0.179 & -0.154 \\
\hline Social capital - Cultural capital & -0.484 & -0.498 & -0.596 \\
\hline Social capital - Private fixed capital & -0.880 & -0.844 & -0.874 \\
\hline Social capital - Natural capital & 0.023 & 0.009 & -0.068 \\
\hline Entrepreneurial milieu - Human capital & 0.692 & 0.638 & 0.634 \\
\hline Entrepreneurial milieu - Infrastructural capital & 0.743 & 0.626 & 0.665 \\
\hline Entrepreneurial milieu - Relational capital & 0.120 & 0.116 & 0.102 \\
\hline Entrepreneurial milieu - Cultural capital & 0.211 & 0.150 & 0.268 \\
\hline Entrepreneurial milieu - Private fixed capital & 0.614 & 0.576 & 0.547 \\
\hline Entrepreneurial milieu - Natural capital & 0.039 & 0.042 & 0.013 \\
\hline Entrepreneurial milieu - Social capital & -0.462 & -0.473 & -0.471 \\
\hline
\end{tabular}

* Over the required results.

Source: Own creation.

Convergent and discriminant validity were used to examine the validity of the latent constructions. Convergent validity, which is a measure of the extent to which the variables in a set can be considered representatives of the same latent variable, can be measured by the average variance extracted (AVE). Here, a value of 0.5 or higher can be accepted (Henseler et al. 2009). Most previous studies evaluate discriminant validity using the Fornell-Larcker criteria, and than examining the cross-

Regional Statistics, Vol. 7. No.1. 2017: 090-1 14; DOI: 10.15196/RS07106 
loadings. However, Henseler et al. (2015) provide examples, based on Monte-Carlo simulations, of when these results are false. They suggest an alternate approach, namely, heterotrait-monotrait (HTMT) correlation ratio (Table 4).

We find that all of the investigated factors have satisfactory test values, except for two of the AVE values. However, although these two AVE values do not reach the expected limit (0.5), but the gap is negligible. Furthermore, the lowest AVE value represents a correlation over 0.69 and, thus, it fits. Composite reliability and HTMT each have one test value under the required level, but these do not cause any problems. Therefore, we include them in our model.

\section{PLS path analysis - the final model}

After testing the latent variables, we focus on the direct relations of the model in order to determine their significance levels. In using the PLS method, we cannot investigate the significance levels of path coefficients directly. Therefore, we use bootstrapping with a high number (5000) of subsamples (see Table 5). Note that the special indicators of social capital indicate that greater values express higher underdevelopment.

Table 5

P-values of the original model, 2009

\begin{tabular}{l|c|c|c}
\hline \multicolumn{1}{c|}{ Path } & $\begin{array}{c}\text { Path } \\
\text { Coefficients }\end{array}$ & T Value & P Value \\
\hline Human capital $\rightarrow$ Cultural capital & 0.123 & 1.573 & 0.116 \\
Human capital $\rightarrow$ Private fixed capital & -0.023 & 0.312 & 0.755 \\
Human capital $\rightarrow$ Social capital & -0.485 & 8.171 & $<0.001$ \\
Human capital $\rightarrow$ Entrepreneurial milieu & 0.511 & 6.168 & $<0.001$ \\
Infrastructural capital $\rightarrow$ Private fixed capital & 0.525 & 6.232 & $<0.001$ \\
Infrastructural capital $\rightarrow$ Entrepreneurial milieu & 0.247 & 1.990 & 0.047 \\
Relational capital $\rightarrow$ Social capital & -0.068 & 0.624 & 0.532 \\
Relational capital $\rightarrow$ Entrepreneurial milieu & 0.070 & 0.642 & 0.521 \\
Cultural capital $\rightarrow$ Relational capital & 0.482 & 2.726 & 0.006 \\
Cultural capital $\rightarrow$ Social capital & -0.307 & 3.460 & 0.001 \\
Cultural capital $\rightarrow$ Entrepreneurial milieu & 0.048 & 0.586 & 0.558 \\
Natural capital $\rightarrow$ Private fixed capital & 0.024 & 0.395 & 0.693 \\
Natural capital $\rightarrow$ Entrepreneurial milieu & 0.009 & 0.142 & 0.887 \\
Social capital $\rightarrow$ Private fixed capital & -0.403 & 6.876 & $<0.001$ \\
Social capital $\rightarrow$ Entrepreneurial milieu & -0.030 & 0.372 & 0.710 \\
Entrepreneurial milieu $\rightarrow$ Private fixed capital & 0.087 & 1.173 & 0.241 \\
$\quad$ Note Significant correlation, with p<0.05. & & & \\
Source: Own creation. & & & \\
& & & \\
\hline
\end{tabular}

Regional Statistics, Vol. 7. No.1. 2017: 090-1 14; DOI: 10.15196/RS07106 
Note that we had to run many tests before the final model was complete. This was necessary because a path indicated as not significant in a given model can be significant in a different model if the paths are changed. The opposite may be true as well. Table 5 shows the significant path between infrastructural capital and private fixed capital, but this is not included in the model for 2009 (Table 6). The pvalues for 2011 and 2013 are shown in Annex II.

Table 6

P-values of the final model, 2009

\begin{tabular}{l|c|c|c}
\hline \multicolumn{1}{c|}{ Path } & Path Coefficients & T Value & P Value \\
\hline Human capital $\rightarrow$ Social capital & -0.488 & 8.820 & $<0.001$ \\
Human capital $\rightarrow$ Entrepreneurial milieu & 0.454 & 6.445 & $<0.001$ \\
Infrastructural capital $\rightarrow$ Entrepreneurial milieu & 0.372 & 4.242 & $<0.001$ \\
Cultural capital $\rightarrow$ Relational capital & 0.507 & 3.560 & $<0.001$ \\
Cultural capital $\rightarrow$ Social capital & -0.344 & 4.839 & $<0.001$ \\
Social capital $\rightarrow$ Private fixed capital & -0.611 & 9.288 & $<0.001$ \\
Entrepreneurial milieu $\rightarrow$ Private fixed capital & 0.326 & 4.326 & $<0.001$
\end{tabular}

Note: Significant correlation, with $\mathrm{p}<0.05$.

Source: Own creation.

After rejecting non significant direct paths, private fixed capital is described by six forms of capital, either directly or indirectly, in the final model and in all three years: two material forms of capital (entrepreneurial milieu, infrastructural capita), and four non-material forms of capital (cultural capital, human capital, social capital, relational capita). It is interesting that natural capital, which had satisfactory test results, has no significant connections to other forms of capital. Nevertheless, the factor is included in the model because this separation can be found as a scientific result.

Similar to the renewed pyramidal model of regional competitiveness (Lengyel 2015, Lengyel-Szakálné Kanó 2012), we identify the success determinants, main factors, and the target in our model (Figure 3). Cultural, relational, human, and infrastructural capital are success determinants, whereas social capital and the entrepreneurial milieu can be defined as the main factors of the model. The target is embodied by private fixed capital, of course.

In 2009 (Figure 3), we find that cultural capital and human capital have an effect on social capital. The cultural factor has a weak impact, while the human element has a moderate influence. In addition, the human capital has a direct effect $(\mathrm{R}=0.454)$ on entrepreneurial milieu. Moreover, this element moderately shapes private fixed capital, indirectly, through social capital and the entrepreneurial milieu $((-0.488) \times(-0.611)+0.454 \times 0.326=0.446)$.

Regional Statistics, Vol. 7. No.1. 2017: 090-114; DOI: 10.15196/RS07106 
Infrastructural capital forms the entrepreneurial milieu directly, with a moderate effect (0.372), as well as private fixed capital. However, the latter indirect effect is rather weak $(0.372 \times 0.326=0.121)$.

Relational capital has a unique role in the model, because it has no effect on the other forms of capital. Cultural capital has a moderate effect on relational capital (0.507).

Interactions of forms of capital explaining private fixed capital, 2009

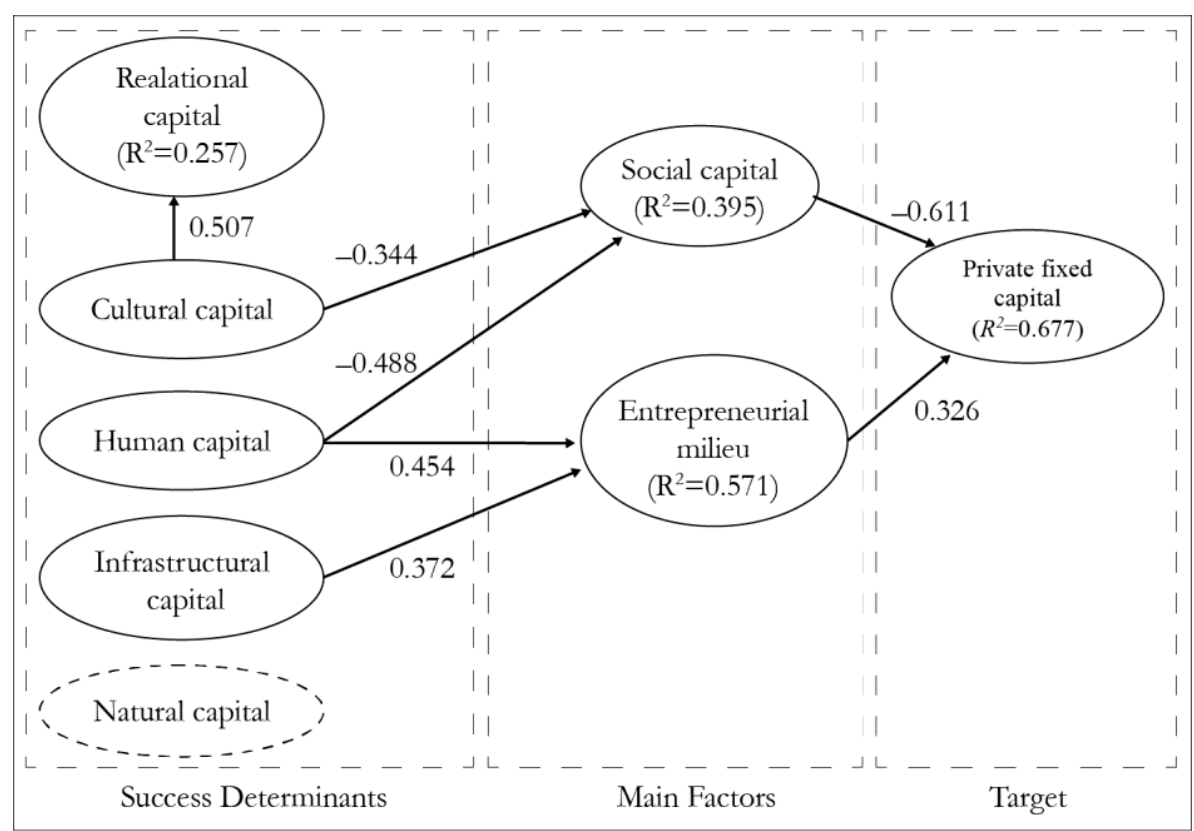

Source: Own creation.

Social capital has a greater impact $(-0.611)$ on private fixed capital, while the effect of the entrepreneurial milieu is much lower (0.326). More than two-thirds of the variance in social capital can be explained by the model, with the remainder (approx. $32 \%$ ) determined by factors outside the model.

It is important to present the values of correlation. In analysing the data, we find there are moderate links between forms of capital. The connection between human and relational capital, and that between human and cultural capital are exceptions. In those cases, we refer to a lack of connection. Otherwise, there is a strong relation between private fixed capital and infrastructural capital (0.811). However, note that infrastructural capital has only an indirect effect on private fixed capital.

We have mentioned the specific nature of indicators of social capital. Thus, the positive correlation between the forms of capital is unambiguous (Table 7).

Regional Statistics, Vol. 7. No.1. 2017: 090-114; DOI: 10.15196/RS07106 
Table 7

Correlations between the forms of capital, 2009

\begin{tabular}{l|r|r|r|r|r|r|r}
\hline & $\begin{array}{r}\text { Human } \\
\text { Capital }\end{array}$ & $\begin{array}{c}\text { Infrastruc- } \\
\text { tural } \\
\text { Capital }\end{array}$ & $\begin{array}{c}\text { Relational } \\
\text { Capital }\end{array}$ & $\begin{array}{c}\text { Cultural } \\
\text { Capital }\end{array}$ & $\begin{array}{c}\text { Private } \\
\text { Fixed Capi- } \\
\text { tal }\end{array}$ & $\begin{array}{c}\text { Social } \\
\text { Capital }\end{array}$ & $\begin{array}{c}\text { Entrepre- } \\
\text { neurial } \\
\text { Milieu }\end{array}$ \\
\hline Human Capital & 1.000 & & & & & & \\
Infrastructural Capital & 0.672 & 1.000 & & & & & \\
Relational Capital & 0.060 & 0.503 & 1.000 & & & & \\
Cultural Capital & 0.115 & 0.473 & 0.507 & 1.000 & & & \\
Private Fixed Capital & 0.602 & 0.811 & 0.271 & 0.337 & 1.000 & & \\
Social Capital & -0.528 & -0.645 & -0.190 & -0.400 & -0.773 & 1.000 & \\
Entrepreneurial Milieu & 0.704 & 0.677 & 0.222 & 0.269 & 0.629 & -0.497 & 1.000
\end{tabular}

Source: Own creation.

Table 8

Values of total effect, 2009

\begin{tabular}{l|c|c|c|c}
\hline & Relational Capital & $\begin{array}{c}\text { Private Fixed } \\
\text { Capital }\end{array}$ & Social Capital & $\begin{array}{c}\text { Entrepreneurial } \\
\text { Milieu }\end{array}$ \\
\hline Human Capital & & 0.446 & -0.488 & 0.454 \\
Infrastructural Capital & 1.000 & 0.121 & & 0.372 \\
Relational Capital & 0.507 & 0.210 & -0.344 & \\
Cultural Capital & & 1.000 & & \\
Private Fixed Capital & & -0.611 & 1.000 & \\
Social Capital & 0.326 & & 1.000 \\
Entrepreneurial Milieu & & & &
\end{tabular}

Source: Own creation.

We use the same method as that of Hetesi and Révész (2013) in order to determine the degree of the direct and indirect affects of the latent variables on private fixed capital. Here, we find that the direct effects are equal to the path coefficients (Figure 3), and that the direct and indirect effects are explained by the total effects (Table 8).

In addition to the direct effects of social capital and the entrepreneurial milieu on private fixed capital, the target variable is shaped indirectly by cultural (0.21) and infrastructural capital (0.121).

In 20114, we find the same interactions in our model. A comparison with 2009 shows that, the same paths have roughly the same weights. Natural capital has no significant connection to the other forms of capital, and relational capital is in the same position (Figure 4).

\footnotetext{
${ }^{4}$ Test values for 2011 and 2013 are provided in Annex II.
} 
We find that four paths strengthened between the two years, but that these changes were negligible. The effect of human capital on social capital and on the entrepreneurial milieu has changed slightly, as has the effect of cultural on social capital. Three paths have weakened (e. g. the link between entrepreneurial milieu and private fixed capital), but again, the changes are not important. In conclusion, in 2011, the variance of private fixed capital decreased slightly, but the change was not important.

Figure 4

Interactions of forms of capital explaining private fixed capital, 2011

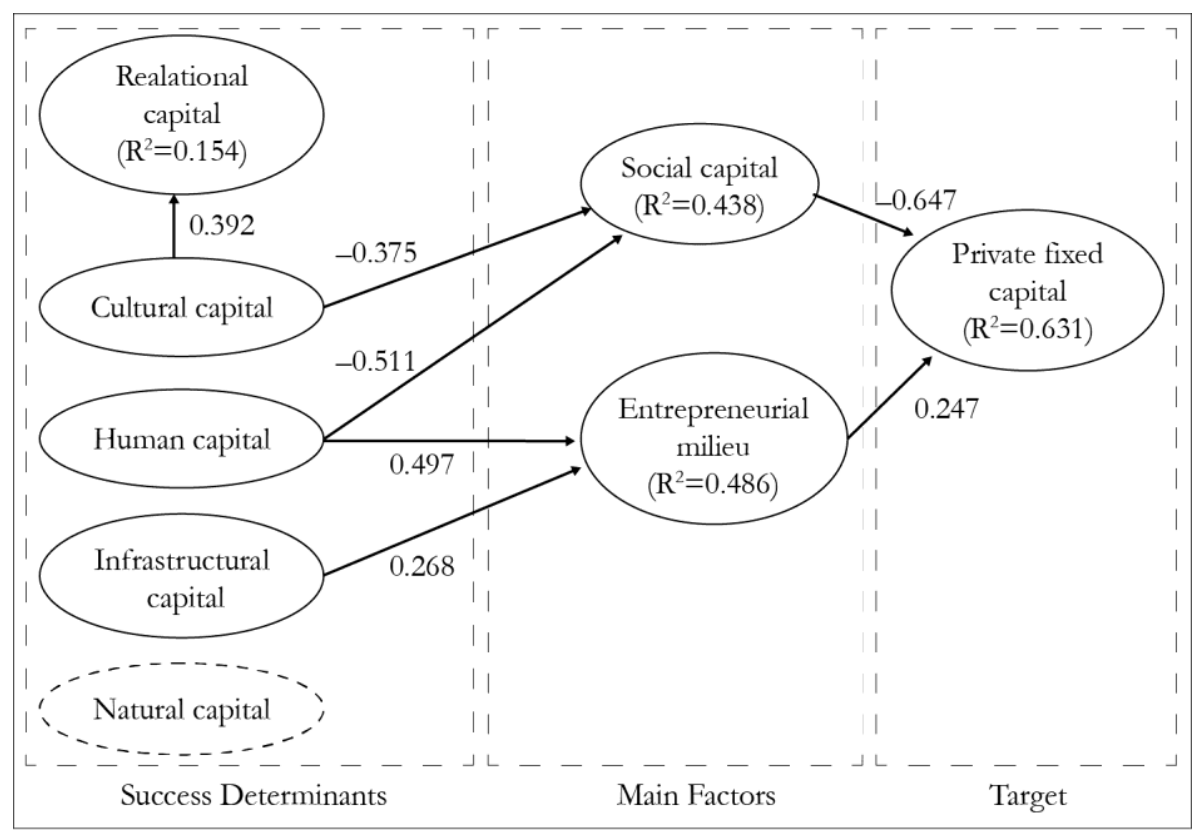

Source: Own creation.

In 2013, we find a different picture (Figure 5), with changes among the paths. The connection between infrastructural capital and the entrepreneurial milieu is no longer significant. Another notable change is that the capital of enterprise performance is formed by relational capital (0.196). The direct effect of infrastructural capital on private fixed capital (0.253) appears as a new path as well. In addition, human capital has an influence on cultural capital (0.205). Thus, the linkages of 2013 are the most similar to the theoretical dependencies of our original model (Figure 2).

Regional Statistics, Vol. 7. No.1. 2017: 090-114; DOI: 10.15196/RS07106 
Interactions of forms of capital explaining private fixed capital, 2013

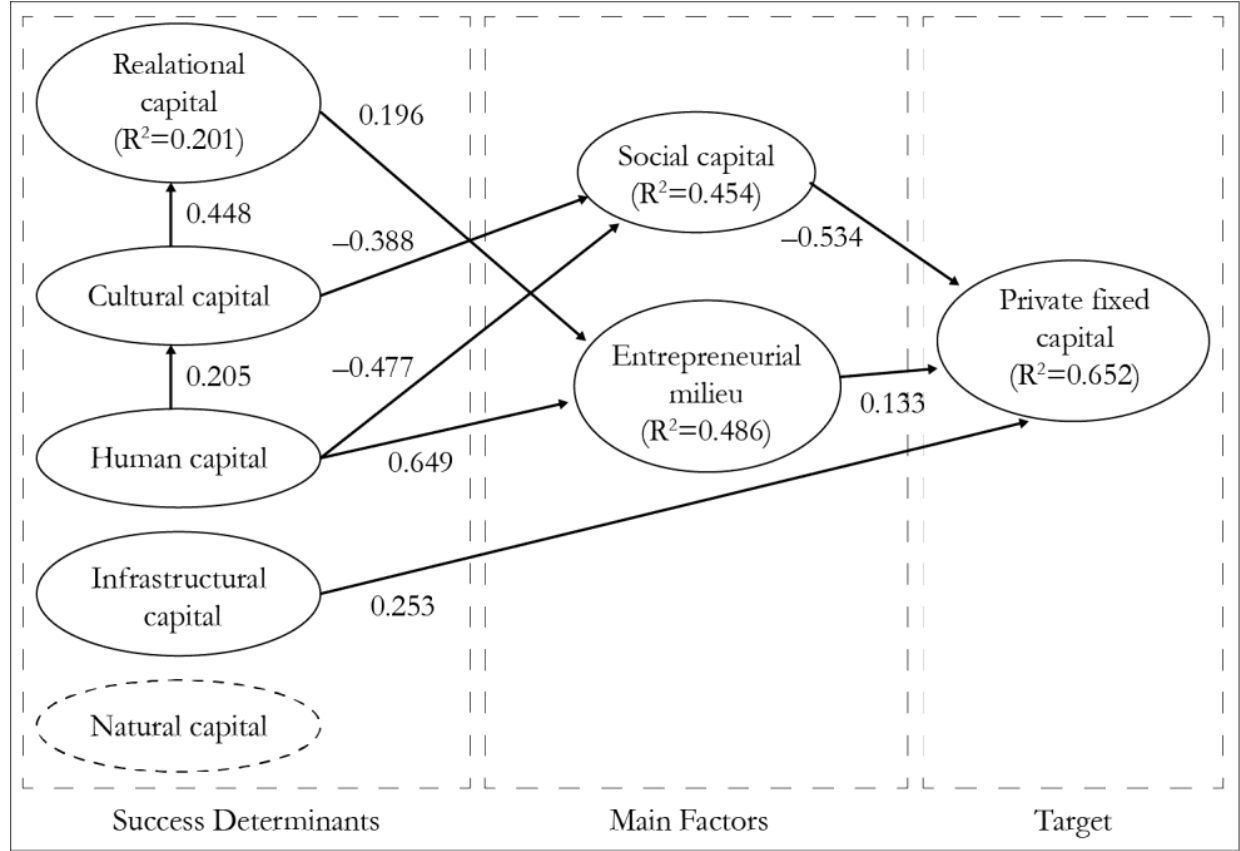

Source: Own creation.

There are smaller changes among the significant paths identified earlier. For example, the effects of cultural capital on relational and social capital are negligible.

There is a weakening of the path between human and social capital. Moreover, both social capital and the entrepreneurial milieu shape the target variable with less of an effect. However, in 2013, the variance of private fixed capital has decreased (0.652). Private fixed capital being formed by social capital $(-0.534)$ is the strongest effect, human capital $(0.387)$ has the most robust indirect effect on private fixed capital.

The roles of the forms of capital in the model are clear because every element has a positive effect on private fixed capital. (As mentioned earlier, human capital includes specific indicators, which is why we find a negative sign.)

Future research should investigate the interaction, or the change of the interaction between endogenous forms of capital in a different context. Our model applies to the countryside, and is able to express rural characteristics well. We ran tests to adapt the model to an urban system ${ }^{5}$, but were unsuccessful owing to poor test values.

\footnotetext{
${ }^{5}$ The focus areas of the tests are shown in Figure 1, excluding Budapest.
} 
Attributes of forms of capital in urban context, 2013

\begin{tabular}{l|c|c|c}
\hline \multicolumn{1}{c|}{ Faktor } & Cronbachs Alpha & Composite Reliability & $\begin{array}{c}\text { Average Variance Extracted } \\
\text { (AVE) }\end{array}$ \\
\hline Human capital & 0.826 & 0.861 & 0.559 \\
Infrastructural capital & 0.702 & 0.806 & $0.464^{*}$ \\
Relational capital & 0.690 & 0.806 & 0.584 \\
Cultural capital & 0.776 & 0.795 & $0.450^{*}$ \\
Private fixed capital & 0.762 & 0.836 & $0.482^{*}$ \\
Natural capital & $0.362^{*}$ & $0.675^{*}$ & $0.485^{*}$ \\
Social capital & 0.709 & 0.787 & 0.524 \\
Entrepreneurial milieu & 0.736 & 0.840 & 0.549 \\
\multicolumn{2}{c}{ * Lower than required result. } & &
\end{tabular}

Natural capital has extremely low test results, but it is self-evident in a metropolitan context. Three other forms of capital have poor AVE-values (see Table 9), while additional bias is also evident. Thus, we emphasize that using the model in an urban milieu can lead to improper conclusions.

We consider it helpful to compare our results to those of other studies. However, this comparison is limited owing to the lack of rural-centric analyses. Jóna (2013) analysed territorial capital, a more specific aspect of endogenous development, and examined the entire sub-region system of Hungary, while Tóth (2013) focused on the measurement of territorial capital in medium-sized Hungarian cities.

Jóna's (2013) work is based on a multivariate regression analysis, and he describes the effects of the forms of capital on territorial capital. He finds that infrastructural and social capital had almost no effect on territorial capital between 2004 and 2010. In the same period, relational and cultural capital had the most remarkable impact.

Note that, in our assessment, social capital has the most important role in forming the dependent variable.

In his work, Tóth (2013) highlights the capital accumulation in Hungarian cities. His analysis is based on constructed material and non-material factors, and he focuses on the correlation coefficients.

Simplifying his statement slightly, there is a strong link between infrastructural and human-cultural capital. If we investigate the correlations between these forms of capital, we find a moderate-to-strong connection between infrastructural and human capital (2009: 0.672; 2011: 0.63; 2013: 0.642), and a moderate connection between infrastructural and cultural capital. However, we find no causal links between the forms of capital, or that they are questionable.

Regional Statistics, Vol. 7. No.1. 2017: 090-114; DOI: 10.15196/RS07106 
Our findings, as well as those of Tóth (2013), and Jóna (2013), show that the use of different territorial approaches may lead to different outcomes, even within similar frameworks.

\section{Conclusions}

In our paper, we attempted to measure the role of endogenous forms of capital in a rural context. The PLS path analysis approach is a novel tool within territorial research, especially if we focus on rural differences. With the help of the method, we showed the interactions between the various forms of capital, as well as their changes over time.

In our model, cultural, relational, human and infrastructural capital are defined as success determinants. The main factors are social capital and the entrepreneurial milieu, while the target variable is private fixed capital.

Investigating the potential of natural capital is left for possible future research. However, being able to determine the appropriate territorial context and level is significant. In our study, we developed a regression model applicable to rural areas, and used it to analyse the interactions between various forms of endogenous capital. Our findings will help to reveal data on the nature of the Hungarian countryside.

\section{REFERENCES}

AEIDL (1999): Territorial competitiveness. Creating a territorial development strategy in light of the LEADER experience. Part 1. LEADER European Observatory AEIDL, Bruxelles, http://ec.europa.eu/agriculture/rur/leader2/rural-en/ biblio/compet/competitivite.pdf (downloaded: 6 May 2013)

Affuso, A.-CAmagni, R. (2010): Territorial capital and province performance in the Latin Arch: an econometric approach. Politecnico di Milano http://www.grupposervizioambiente.it/aisre/pendrive2010/pendrive/Paper/aff uso1.pdf (downloaded: 12 November 2014)

Atkinson, R. (2013): Territorial Capital, Attractiveness and the Place-based Approach: the Potential Implications for Territorial Development In: PÁLNÉ KOVÁCS, I.-SCOTT, J.-GÁL, Z. (eds): Territorial Cohesion in Europe. For the 70th Anniversary of the Transdanubian Research Institute pp. 297-308., IRS CERS HAS, Pécs.

Braithwaite, K. (2009): Building on What You Have Got - A Guide to Optimising Assets. Carnegie UK Trust, Dunfermline, UK.

Brasili, C.-SAguAtTi, A.-Benni, F.-MArchese, A.-GANdolfo, D. (2012): The Impact of the Economic Crisis on the Territorial Capital of Italian Regions 52nd European Regional Science Congress, Bratislava, Slovakia, August 21-25, 2012, http://www-sre.wu.ac.at/ersa/ersaconfs/ersa12/e120821aFinal00646.pdf (downloaded: 12 November 2014)

CAMAgni, R. (2008): Regional competitiveness: towards a concept of territorial capital In: CApello, R.-CAmagni, R.-Chizzolini, B.-Fratesi, U. (eds): Modelling regional scenarios for the enlarged Europe pp. 33-47., Springer-Verlag, Berlin.

Regional Statistics, Vol. 7. No.1. 2017: 090-1 14; DOI: 10.15196/RS07106 
Camagni, R.-Caragliu, A.-Perucca, G. (2011): Territorial capital. Relational and human capital. (draft version) Politecnico di Milano, http://www.grupposer vizioambiente.it/aisre_sito/doc/papers/Camagni_Caragliu_Perucca.pdf (downloaded: 2 July 2015)

CAPELlO, R. (2007): Regional Economics Routledge, Oxon.

Capello, R.-CARagliu, A.-NiJKamp, P. (2009): Territorial Capital and Regional Growth: Increasing Returns in Cognitive Knowledge Use. Tinbergen Institute Discussion Paper. http:/ / papers.tinbergen.nl/09059.pdf (downloaded: 28 September 2012)

Csatári, B. (2001): A vidék földrajzi kérdései In: DORMÁNY, G.-KOVÁCs F.-PÉTI M.RAKONCZAi J. (eds.): A földrajz eredményei az új évezred küszöbén pp. 1-9., SZTE TTK Természeti Földrajzi és Geoinformatikai Tanszék, Szeged. http://geography.hu/mfk2001/cikkek/Csatari.pdf (downloaded: 8 October 2010)

DiMaggio, P. (2004): Cultural Capital In: Ritzer, G. (eds): Encyclopedia of Social Theory pp. 167-170., SAGE Publications, Thousand Oaks-London-New Delhi.

DiNYA, L. (2013): „Zöld” prioritások érvényesítése a megyei szintű területfejlesztési stratégiákban Journal of Central European Green Innovation 1 (1): 21-33.

EC (1999): European Spatial Development Perspective. Towards Balanced and Sustainable Development of the Territory of the European Union European Commission, Luxembourg.

ETC (2007): Learning Endogenous Development - Building on Bio-cultural Diversity ETC Foundation - Compas, Bourton on Dunsmore, Rugby, Warwickshire, UK.

Hair, J. F.-SARStedt, M.-PiePer, T. M.-Ringle, C. M. (2012): The Use of Partial Least Squares Structural Equation Modeling in Strategic Management Research: A Review of Past Practices and Recommendations for Future Applications Long Range Planning 45 (5-6): 320-340.

HENSELER, J. (2010): On the convergence of the partial least squares path modeling algorithm Computational Statistics 25 (1): 107-120.

Henseler, J.-Ringle, C. M.-Sinkovics, R. R. (2009): The use of partial least squares path modeling in international marketing New Challenges to International Marketing: Advances in International Marketing 20: 277-319.

Henseler, J.-Ringle, C. M.-SARstedt, M. (2015): A New Criterion for Assessing Discriminant Validity in Variance-based Structural Equation Modeling Journal of the Academy of Marketing Science 43 (1): 115-135.

Hetesi, E.-RÉvÉsz, B. (2013): Melyik a fontosabb? Információs technológia alapú és személyes kapcsolatok a business marketingben In: TOMPOS, A.-ABLONCZYNÉ MiHÁLYKA, L. (eds.): Növekedés és egyensúly pp. 1-16., Kautz Gyula Emlékkonferencia, June 11, 2013, Széchenyi István Egyetem Kautz Gyula Gazdaságtudományi Kar Győr, Hungary. http://kgk.sze.hu/images/dokumentumok /kautzkiadvany2013/marketing/hetesi_revesz.pdf (downloaded: 15 April 2015)

JónA, Gy. (2013): A területi tóke kistérségi jellegzetességei Doctoral dissertation Szent István Egyetem Enyedi György Regionális Tudományok Doktori Iskola, Gödöllő.

KAZÁR, K. (2014): A PLS-útelemzés és alkalmazása egy márkaközösség pszichológiai érzetének vizsgálatára Statisztikai Szemle 92 (1): 33-52.

Regional Statistics, Vol. 7. No.1. 2017: 090-1 14; DOI: 10.15196/RS07106 
KovÁcs, P.-BODNÁR, G. (2016): Az endogén fejlődés vidéki értelmezése a PLS-útelemzés segítségével Statisztikai Szemle 94 (2): 143-161.

LENGYEL, I. (2012): A hazai területfejlesztés zsákutcái: a triális Magyarország In: RECHNITZER, J.-RÁCZ, SZ. (eds.): Dialógus a regionális tudományról pp. 140-150., Széchenyi István Egyetem Regionális- és Gazdaságtudományi Doktori Iskola, Magyar Regionális Tudományi Társaság, Győr.

LENGYEL, I. (2015): A magyar térségek versenyképessége: kényszerpályák vagy kitörési lehetôségek? Térségek versenyképessége, intelligens szakosodása és újraiparosodása. Tudományos konferencia a szegedi regionális versenyképességi kutatások 15 éves jubileuma alkalmából. October 13-14. 2015., Szegedi Tudományegyetem Gazdaságtudományi Kar, Szeged.

LENGYEL, I.-SZAKÁLNÉ KANÓ, I. (2012): Competitiveness of Hungarian Urban Microregions: Localization Agglomeration Economies and Regional Competitiveness Function Regional Statistics 2 (2): 27-44.

Milone, P.-VenturA, F.-Berti, G.-Brunori, G. (2010): Some Notes on the Identification of Rural Webs In: Milone, P.-VenturA, F. (eds): Networking the Rural pp. 30-48., Royal Van Gorcum, Assen, The Netherlands.

MÜNNICH, Á.-HidEGKUTI, I. (2012): Strukturális egyenletek modelljei: oksági viszonyok és komplex elméletek vizsgálata pszichológiai kutatásokban Alkalmazott Pszichológia 1: 77-102.

Perlín, R.-SimcikovÁ, A. (2008): Criteria of a successful rural municipality Europa XXI 17: 29-43.

Putnam, R. D. (1996): Who killed civic America? Prospect 7: 66-72.

Stimson, R.-STOUgh, R. R.-NiJKAmp. P. (2011): Endogenous Regional Development In: Stimson, R.-Stough, R. R.-Nijkamp. P. (eds): Endogenous Regional Development. Perspectives, Measurement and Empirical Investigation pp. 1-19., Edward Elgar, Cheltenham, UK - Northampton, MA, USA.

ReChnitzer, J. (2016): A területi tôke a városfejlódésben. A Gyôr-kód Dialóg Campus Kiadó, Budapest-Pécs.

SZAKÁLNÉ KANÓ, I. (2008): Regressziószámítás alkalmazása kistérségi adatokon In: LENGYEL, I.-Lukovics, M. (eds.): Kérdôjelek a régiók gazdasági fejlôdésében pp. 264-287., JATEPress, Szeged.

TótH, B. I. (2013): A területi tóke szerepe a regionális- és városfejlódésben - Esettanulmány a magyar középvárosok példáján Doctoral Dissertation Nyugat-magyarországi Egyetem Széchenyi István Gazdálkodás- és Szervezéstudományok Doktori Iskola, Sopron.

Vermeire, B.-Gellynck, X.-De STEUR, H.-Viaene, J. (2008): The role of social capital assets in reconciling endogenous and exogenous drivers of rural renewal. $8^{\text {th }} \mathrm{Eu}-$ ropean IFSA Symposium, 6-10 July 2008, Clermont-Ferrand, France, http://ifsa.boku.ac.at/cms/fileadmin/Proceeding2008/2008_WS6_06_ Vermeire.pdf (downloaded: 21 July 2014)

Regional Statistics, Vol. 7. No.1. 2017: 090-114; DOI: 10.15196/RS07106 
ANNEX I.

Indicators of each capitals, 2013

\begin{tabular}{|c|c|}
\hline Forms of Capital & Indicator \\
\hline \multirow{8}{*}{ Private fixed capital } & Material capital \\
\hline & Licensed traditional small-scale producing income $(\mathrm{Ft})$ per capita \\
\hline & Total domestic income $(\mathrm{Ft})$ per capita \\
\hline & Total income of full-time jobs $(\mathrm{Ft})$ per capita \\
\hline & Number of built properties per 1,000 inhabitants \\
\hline & $\begin{array}{l}\text { Total floor area }\left(\mathrm{m}^{2}\right) \text { of built properties in the same year per 1,000 inhabit- } \\
\text { ants }\end{array}$ \\
\hline & Total number of taxpayers per 1,000 inhabitants \\
\hline & Number of passenger cars by residence of operator per 1,000 inhabitants \\
\hline \multirow{7}{*}{ Entrepreneurial milieu } & Gross value added $(1,000 \mathrm{Ft})$ per registered entrepreneurship \\
\hline & Balance sheet total (total assets) (1,000 Ft) per registered entrepreneurship \\
\hline & Number of registered limited partnerships per 1,000 inhabitants \\
\hline & Number of registered limited companies per 1,000 inhabitants \\
\hline & Number of registered agricultural cooperatives per 1,000 inhabitants \\
\hline & Number of registered limited liability companies per 1,000 inhabitants \\
\hline & Number of registered joint venture per 1,000 inhabitants - GFO'11 \\
\hline \multirow{5}{*}{ Infrastructural capital } & Amount of electricity $(1,000 \mathrm{kWh})$ of households per 1,000 inhabitants \\
\hline & $\begin{array}{l}\text { Length of electricity network only for public lighting per 1,000 inhabitants } \\
(\mathrm{km})\end{array}$ \\
\hline & $\begin{array}{l}\text { Amount of sewage disposal in public collecting system per 1,000 inhabitants } \\
(1,000 \mathrm{~m} 3)\end{array}$ \\
\hline & $\begin{array}{l}\text { Number of broadband subscriptions at the end of the year per 1,000 inhab- } \\
\text { itants }\end{array}$ \\
\hline & Number of telephone lines (including ISDN lines) per 1,000 inhabitants \\
\hline \multirow{3}{*}{ Natural capital } & Areas of other parts (forest, ha) per 1,000 inhabitants \\
\hline & Forest area (ha) per 1,000 inhabitants \\
\hline & Green area (ha) per 1,000 inhabitants \\
\hline \multirow{6}{*}{ Social capital } & Non-material capital \\
\hline & $\begin{array}{l}\text { Total number of registered long-term (180 days) job-seekers per 1,000 inhab- } \\
\text { itants }\end{array}$ \\
\hline & Number of constant replacement migration per 1,000 inhabitants \\
\hline & $\begin{array}{l}\text { Number of full-time pedagogues in primary education per 1,000 inhabitants } \\
\text { (including specific education) }\end{array}$ \\
\hline & $\begin{array}{l}\text { Number of juvenile offenders (year 14-17) within registered offenders per } \\
1,000 \text { inhabitants }\end{array}$ \\
\hline & Number of registered offenders (by location) per 1,000 inhabitants \\
\hline
\end{tabular}

(Table continues on the next page.)

Regional Statistics, Vol. 7. No.1. 2017: 090-114; DOI: 10.15196/RS07106 
(Continued.)

\begin{tabular}{|c|c|}
\hline Forms of Capital & Indicator \\
\hline Human capital & $\begin{array}{l}\text { Number of full-time students in tertiary education per 1,000 inhabitants (by } \\
\text { location) } \\
\text { Number of lecturers in tertiary education per 1,000 inhabitants (by location) } \\
\text { Number of high-tech processing industry (pc.) per 1,000 inhabitants } \\
\text { Number of medium high-tech processing industry (pc.) per 1,000 inhabitants } \\
\text { Number of knowledge-intensive services (pc.) per 1,000 inhabitants }\end{array}$ \\
\hline Cultural capital & $\begin{array}{l}\text { Number of creative cultural collectivities per } 1,000 \text { inhabitants } \\
\text { Number of members of creative cultural collectivities per } 1,000 \text { inhabitants } \\
\text { Number of cultural events per } 1,000 \text { inhabitants } \\
\text { Number of participants of cultural events per } 1,000 \text { inhabitants } \\
\text { Number of visitors of museums per } 1,000 \text { inhabitants } \\
\text { Number of participants of regular forms of culture per } 1,000 \text { inhabitants }\end{array}$ \\
\hline Relational capital & $\begin{array}{l}\text { Number of nights spent at rural tourist accommodation establishments per } \\
1,000 \text { inhabitants (by non-residents) } \\
\text { Length of fastest path to Budapest by time optimization (from the centre of } \\
\text { sub-region) } \\
\text { Number of nights spent at tourist accommodation establishments per 1,000 } \\
\text { inhabitants (by non-residents) } \\
\text { Number of total guests at tourist accommodation establishments per 1,000 } \\
\text { inhabitants } \\
\text { Number of nights spent at tourist accommodation establishments per 1,000 } \\
\text { inhabitants }\end{array}$ \\
\hline
\end{tabular}

Note: Some indicators have different names in 2009 and in 2011. These negligible differences have no influence on the dynamic analysis.

Source: Own creation.

Regional Statistics, Vol. 7. No.1. 2017: 090-1 14; DOI: 10.15196/RS07106 
ANNEX II.

\section{Test values of PLS Path Analysis}

Values of the year 2011

P Values of the original model, 2011

\begin{tabular}{l|c|c|r}
\hline \multicolumn{1}{c|}{ Path } & $\begin{array}{c}\text { Path } \\
\text { Coefficients }\end{array}$ & T Value & P Value \\
\hline Human capital $\rightarrow$ Cultural capital & 0.104 & 1.227 & 0.220 \\
Human capital $\rightarrow$ Private fixed capital & 0.025 & 0.287 & 0.774 \\
Human capital $\rightarrow$ Social capital & -0.492 & 8.831 & $<0.001$ \\
Human capital $\rightarrow$ Entrepreneurial milieu & 0.579 & 6.823 & $<0.001$ \\
Infrastructural capital $\rightarrow$ Private fixed capital & 0.287 & 2.863 & 0.004 \\
Infrastructural capital $\rightarrow$ Entrepreneurial milieu & 0.073 & 0.471 & 0.638 \\
Relational capital $\rightarrow$ Social capital & -0.151 & 2.195 & 0.028 \\
Relational capital $\rightarrow$ Entrepreneurial milieu & 0.171 & 1.726 & 0.084 \\
Cultural capital $\rightarrow$ Relational capital & 0.387 & 3.224 & 0.001 \\
Cultural capital $\rightarrow$ Social capital & -0.311 & 4.944 & $<0.001$ \\
Cultural capital $\rightarrow$ Entrepreneurial milieu & 0.050 & 0.678 & 0.498 \\
Natural capital $\rightarrow$ Private fixed capital & 0.082 & 1.288 & 0.198 \\
Natural capital $\rightarrow$ Entrepreneurial milieu & 0.017 & 0.291 & 0.771 \\
Social capital $\rightarrow$ Private fixed capital & -0.461 & 6.269 & $<0.001$ \\
Social capital $\rightarrow$ Entrepreneurial milieu & -0.023 & 0.246 & 0.806 \\
Entrepreneurial milieu $\rightarrow$ Private fixed capital & 0.148 & 1.504 & 0.133
\end{tabular}

Note: Significant correlation, with $\mathrm{p}<0.05$.

Source: Own creation.

P Values of the final model, 2011

\begin{tabular}{l|c|c|c}
\hline \multicolumn{1}{c|}{ Path } & Path Coefficients & T Value & P Value \\
\hline Human capital $\rightarrow$ Social capital & -0.511 & 9.475 & $<0.001$ \\
Human capital $\rightarrow$ Entrepreneurial milieu & 0.497 & 6.843 & $<0.001$ \\
Infrastructural capital $\rightarrow$ Entrepreneurial milieu & 0.268 & 2.263 & 0.024 \\
Cultural capital $\rightarrow$ Relational capital & 0.392 & 3.646 & $<0.001$ \\
Cultural capital $\rightarrow$ Social capital & -0.375 & 6.189 & $<0.001$ \\
Social capital $\rightarrow$ Private fixed capital & -0.647 & 9.973 & $<0.001$ \\
Entrepreneurial milieu $\rightarrow$ Private fixed capital & 0.247 & 2.776 & 0.006
\end{tabular}

Note: Significant correlation, with $\mathrm{p}<0.05$.

Source: Own creation.

Regional Statistics, Vol. 7. No.1. 2017: 090-1 14; DOI: 10.15196/RS07106 
Correlation between the capitals, 2011

\begin{tabular}{l|r|r|r|r|r|r|r}
\hline & $\begin{array}{c}\text { Human } \\
\text { capital }\end{array}$ & $\begin{array}{c}\text { Infra- } \\
\text { structural } \\
\text { capital }\end{array}$ & $\begin{array}{c}\text { Relational } \\
\text { capital }\end{array}$ & $\begin{array}{c}\text { Cultural } \\
\text { capital }\end{array}$ & $\begin{array}{c}\text { Private } \\
\text { fixed } \\
\text { capital }\end{array}$ & $\begin{array}{c}\text { Social } \\
\text { capital }\end{array}$ & $\begin{array}{c}\text { Entrepre- } \\
\text { neurial } \\
\text { milieu }\end{array}$ \\
\hline Human capital & 1.000 & & & & & & \\
Infrastructural capital & 0.630 & 1.000 & & & & & \\
Relational capital & 0.075 & 0.503 & 1.000 & & & & \\
Cultural capital & 0.096 & 0.508 & 0.392 & 1.000 & & & \\
Private fixed capital & 0.555 & 0.740 & 0.278 & 0.340 & 1.000 & & \\
Social capital & -0.547 & -0.741 & -0.275 & -0.424 & -0.764 & 1.000 & \\
Entrepreneurial milieu & 0.666 & 0.581 & 0.232 & 0.223 & 0.554 & -0.474 & 1.000
\end{tabular}

Note: Significant correlation, with $\mathrm{p}<0.05$.

Source: Own creation.

Values of Total Effect, 2011

\begin{tabular}{l|c|c|c|c}
\hline & Relational capital & $\begin{array}{c}\text { Private fixed } \\
\text { capital }\end{array}$ & Social capital & $\begin{array}{c}\text { Entrepreneurial } \\
\text { milieu }\end{array}$ \\
\hline Human capital & & 0.453 & -0.511 & 0.497 \\
Infrastructural capital & 1.000 & 0.066 & & 0.268 \\
Relational capital & 0.392 & 0.243 & -0.375 & \\
Cultural capital & & 1.000 & & \\
Private fixed capital & & -0.647 & 1.000 & \\
Social capital & 0.247 & & 1.000 \\
Entrepreneurial milieu & & & &
\end{tabular}

Note. Significant correlation, with $\mathrm{p}<0.05$.

Source: Own creation. 


\section{Values of the year 2013}

P Values of the original model, 2013

\begin{tabular}{l|c|c|c}
\hline \multicolumn{1}{c|}{ Path } & Path Coefficients & T Value & P Value \\
\hline Human capital $\rightarrow$ Cultural capital & 0.201 & 2.309 & 0.021 \\
Human capital $\rightarrow$ Private fixed capital & 0.061 & 0.598 & 0.550 \\
Human capital $\rightarrow$ Social capital & -0.471 & 8.123 & 0.000 \\
Human capital $\rightarrow$ Entrepreneurial milieu & 0.577 & 5.463 & 0.000 \\
Infrastructural capital $\rightarrow$ Private fixed capital & 0.232 & 2.149 & 0.032 \\
Infrastructural capital $\rightarrow$ Entrepreneurial milieu & 0.095 & 0.526 & 0.599 \\
Relational capital $\rightarrow$ Social capital & -0.110 & 1.585 & 0.113 \\
Relational capital $\rightarrow$ Entrepreneurial milieu & 0.128 & 0.962 & 0.336 \\
Cultural capital $\rightarrow$ Relational capital & 0.452 & 2.701 & 0.007 \\
Cultural capital $\rightarrow$ Social capital & -0.341 & 4.557 & 0.000 \\
Cultural capital $\rightarrow$ Entrepreneurial milieu & 0.080 & 1.000 & 0.317 \\
Natural capital $\rightarrow$ Private fixed capital & 0.040 & 0.515 & 0.606 \\
Natural capital $\rightarrow$ Entrepreneurial milieu & 0.034 & 0.547 & 0.584 \\
Social capital $\rightarrow$ Private fixed capital & -0.522 & 6.889 & 0.000 \\
Social capital $\rightarrow$ Entrepreneurial milieu & 0.008 & 0.090 & 0.928 \\
Entrepreneurial milieu $\rightarrow$ Private fixed capital & 0.108 & 1.262 & 0.207
\end{tabular}

Note: Significant correlation, with $\mathrm{p}<0.05$.

Source: Own creation.

P Values of the final model, 2013

\begin{tabular}{l|c|c|c}
\hline \multicolumn{1}{c|}{ Path } & Path Coefficients & T Value & P Value \\
\hline Human capital $\rightarrow$ Cultural capital & 0.205 & 2.265 & 0.024 \\
Human capital $\rightarrow$ Social capital & -0.477 & 8.532 & 0.000 \\
Human capital $\rightarrow$ Entrepreneurial milieu & 0.649 & 14.457 & 0.000 \\
Infrastructural capital $\rightarrow$ Private fixed capital & 0.253 & 2.575 & 0.010 \\
Relational capital $\rightarrow$ Entrepreneurial milieu & 0.196 & 2.167 & 0.030 \\
Cultural capital $\rightarrow$ Relational capital & 0.448 & 2.948 & 0.003 \\
Cultural capital $\rightarrow$ Social capital & -0.388 & 5.727 & 0.000 \\
Social capital $\rightarrow$ Private fixed capital & -0.534 & 7.297 & 0.000 \\
Entrepreneurial milieu $\rightarrow$ Private fixed capital & 0.133 & 1.954 & $0.051^{*}$
\end{tabular}

Note I: Significant correlation, with $\mathrm{p}<0.05$.

Note II: ${ }^{*}$ it is involved to the analysis by our decision.

Source: Own creation.

Regional Statistics, Vol. 7. No.1. 2017: 090-114; DOI: 10.15196/RS07106 
Correlation between the forms of capital, 2013

\begin{tabular}{l|r|r|r|r|r|r|r}
\hline & $\begin{array}{c}\text { Human } \\
\text { capital }\end{array}$ & $\begin{array}{c}\text { Infra- } \\
\text { structural } \\
\text { capital }\end{array}$ & $\begin{array}{c}\text { Relational } \\
\text { capital }\end{array}$ & $\begin{array}{c}\text { Cultural } \\
\text { capital }\end{array}$ & $\begin{array}{c}\text { Private } \\
\text { fixed } \\
\text { capital }\end{array}$ & $\begin{array}{c}\text { Social } \\
\text { capital }\end{array}$ & $\begin{array}{c}\text { Entrepre- } \\
\text { neurial } \\
\text { milieu }\end{array}$ \\
\hline Human capital & 1.000 & & & & & & \\
Infrastructural capital & 0.642 & 1.000 & & & & & \\
Relational capital & 0.103 & 0.571 & 1.000 & & & & \\
Cultural capital & 0.205 & 0.489 & 0.448 & 1.000 & & & \\
Private fixed capital & 0.570 & 0.688 & 0.332 & 0.322 & 1.000 & & \\
Social capital & -0.557 & -0.672 & -0.306 & -0.486 & -0.765 & 1.000 & \\
Entrepreneurial milieu & 0.670 & 0.567 & 0.262 & 0.300 & 0.521 & -0.456 & 1.000
\end{tabular}

Source: Own creation.

Values of Total Effect, 2013

\begin{tabular}{l|c|c|c|c|c}
\hline & $\begin{array}{c}\text { Relational } \\
\text { capital }\end{array}$ & $\begin{array}{c}\text { Cultural } \\
\text { capital }\end{array}$ & $\begin{array}{c}\text { Private fixed } \\
\text { capital }\end{array}$ & Social capital & $\begin{array}{c}\text { Entrepreneurial } \\
\text { milieu }\end{array}$ \\
\hline Human capital & 0.092 & 0.205 & 0.387 & -0.557 & 0.667 \\
Infrastructural capital & 1.000 & & 0.253 & & \\
Relational capital & 0.448 & 1.000 & 0.219 & -0.388 & 0.196 \\
Cultural capital & & & 1.000 & & 0.088 \\
Private fixed capital & & & -0.534 & 1.000 & \\
Social capital & & 0.133 & & 1.000 \\
Entrepreneurial milieu & & & & &
\end{tabular}

Source: Own creation. 